\title{
Influence of external factors on the preservation of human nervous tissue for histological studies: review article
}

\author{
Influência dos fatores externos sobre a preservação do tecido nervoso bumano \\ nos estudos histológicos: artigo de revisão
}

Bruno Lopes dos Santos ${ }^{1}$; Elaine Aparecida Del-Bel²; José Eymard Homem Pittella³; Vitor Tumas ${ }^{4}$

\begin{abstract}
Neuropathological studies are crucial for the new knowledge on pathophysiology and treatment of neurodegenerative diseases, such as Alzheimer's disease and Parkinson's disease. The postmortem brain tissue processing method directly impacts on both the appropriate integrity and the biomolecules detection by different histological and molecular biology techniques. In this review we will discuss topics on the influence of someexternalfactors on the reservation of thebrain tissuefor histological studies (histochemistry and immunohistochemistry), such as factors either prior or after the death, and the chosen method for the preservation of nervous tissue. By means of a specific example, we propose a strict record of various conditions involved in the method of preservation of nervous tissue, and its correlation with variables that measure the quality of the histological sample as markers of preservation of biological material for further studies.
\end{abstract}

Key words: postmortem human brain tissue; brain bank; neuropathology; agonal state; fixation; freezing.

\section{INTRODUCTION}

Neuropathological examinations are based on the preservation of the nervous system structures after the death for long periods of time in order to enable appropriate analysis of the macroscopic and microscopic findings of brain, spinal cord, and cranial nerves. The increasing demand for studies on brain of individuals with neurodegenerative diseases, such as Alzheimer's disease and Parkinson's disease, gave rise to groups that had the initiative to store the material for further studies, known as "Brain Bank". Thus, the preservation techniques are essential for ensuring the detection of proteins and other biomolecules and to prevent histological artifacts.

In this review, we will restrict the preparation of postmortem brain tissue analysis for histological studies. Aiming at improving the quality of the biological material, we will review three groups of factors with great impact on brain tissue preservation for analysis by histological techniques (such as histochemistry and immunohistochemistry): brain premortem conditions, brain postmortem conditions, and the chosen method for brain tissue conservation. As a conservation method, we present the protocol based on aldehyde fixation of the material, followed by cryoprotection and freezing, because it is an effective and widely used method of preservation before the nervous tissue storage. In order to reduce the interference of these factors on the final quality of the stored nervous tissue, we propose an analysis model based on linear regression that can be used as a marker of brain tissue conservation quality.

\section{BRAIN PREMORTEM CONDITIONS}

Pathological studies on postmortem human nervous tissue should consider the numerous factors that may act on this type of material, such as individual's status prior to death, corpse

First submission on 23/02/14; last submission on $02 / 10 / 14$; accepted for publication on $05 / 10 / 14$; published on 20/12/14

1. MSc in Neurology at Ribeirão Preto Medical School-University of São Paulo (USP).

2. PhD in Pharmacology at Ribeirão Preto Medical School-USP; associate professor at Ribeirão Preto School of Dentistry-USP.

3. PhD in Pathology at Federal University of Minas Gerais (UFMG); neuropathologist at Ribeirão Preto Medical School-USP.

4. PhD in Neurology at Ribeirão Preto Medical School-USP; associate professor at Ribeirão Preto Medical School-USP. 
conditions after the death, method of brain removal and storage, and its histological processing. These variables are not always taken into account as the origin of biases in analysis, and they may interfere with the robustness of the data collected and results obtained in the studies.

Data about previous comorbidities of the subjects before death can be used for selecting individuals by pre defined criteria, and a better matching of neuropathological study groups. Besides serving as a selection parameter, the recording of these variables can be used to compare these data with the final results of the analysis. Among premortem conditions, we quote:

a) age: it is known the expression of certain proteins and other macromolecules in the nervous system may vary throughout lifetime, especially in the context of neurological disease. It is possible that aging could reduce the stability of deoxyribonucleic acid (DNA) and of messenger ribonucleic acid (mRNA) in human brain, probably by increasing enzymatic activity, such as ribonuclease ${ }^{(13)}$. Data on stability throughout lifetime are conflicting: levels of different proteins in the central nervous system can increase, decrease or be stable according to age group ${ }^{(13)}$;

b) sex: the influence of gender in the expression of molecules on brain has been increasingly studied, and different concentrations and activity levels among individuals of the same species and different sexes are reported. As an example, it was shown that mRNA expression of genes related to serotonin and dopamine receptors is reduced in men, and specific fractions of opioid receptors are most frequently found in women ${ }^{(13)}$;

c) clinical conditions: for a good selection of human brains for postmortem studies purposes, obtaining information on individual's previous conditions is essential (mainly neurological and psychiatric disorders, such as epilepsy, stroke, neurodegenerative diseases, alcohol abuse, psychotic and affective disorders), as well as specific clinical conditions of the terminal stage of life (fever and infections with septic shock, convulsive seizures, and coma);

d) medication: the chronic use of certain medications can affect the detection of molecules in the brain, for example, the long-term use of opioid analgesics can change the synaptic pattern of neurons ${ }^{(13)}$. In addition, many other neuroactive drugs modify the expression and activity of protein in the central nervous system ${ }^{(13)}$;

e) agonal state: agonal state is defined as the clinical status of patient prior to death, and it is associated with events such as fever, dehydration, metabolic and acid-base disorders, hypoglicemia, hypotension, hypoxia, and coma ${ }^{(11)}$. This variable has a strong impact on postmortem tissue, since numerous individuals selected to pathological studies, had prolonged death associated to infections, mechanical ventilation, use of vasoactive drugs, and coma ${ }^{(13)}$. The agonal state can affect the $\mathrm{pH}$ of brain nervous tissue, usually by hypoxia and/or lactic acidosis leading to potential modifications on the stability of some proteins and enzymes $^{(13)}$. Individuals suffering prolonged death have more acid $\mathrm{pH}$ levels in their brains ${ }^{(10,13,16)}$.

It is unknown whether hyperthermia, which stimulates the production of acute-phase proteins, and hypoglycemia, which induces anaerobic metabolism and systemic $\mathrm{pH}$ decrease, can cause other changes in postmortem nervous tissue ${ }^{(11,13)}$. Coma can result in substantial neurochemical changes, and its duration beyond 24 hours is associated with reduction of certain molecules expression in the brain, such as $\mathrm{M}_{1}$ muscarinic receptor and feniletanol amine $\mathrm{N}$-methyltransferase ${ }^{(13,14)}$. In general, proteins and their epitopes seems to be resistant to changes induced by agonal state, with some exceptions, as enzyme glutamate decarboxylase ${ }^{(13)}$.

Tomita et al. ${ }^{(21)}$ compared the influence of agonal state variables (coma, fever, dehydration, etc.) and postmortem variables (postmortem interval, body cooling time) on the quality of mRNA for molecular biology studies in human brains using a score, and it was observed that agonal period is more important in determining the biological material final quality for the molecular study than the postmortem conditions.

Recently, a new scale for agonal state was developed (Table $)^{(19)}$, consisting of 10 criteria, with variable scoring. One of these criteria (mode of death) is based on the type of individual's death ${ }^{(10)}$ : rapid and violent death (1 point) accidental death, death by polytrauma or suicide, with agonal state estimated in less than 10 minutes; rapid death from natural causes (2 points): sudden unexpected death of individuals who had no previous diseases, with agonal state estimated in less than 1 hour (e.g., acute myocardial infarction); intermediary death (3 points): death with agonal state between 1 and 24 hours; slow death (4 points): death after long-term illness, with terminal stage longer than one day, usually including individuals in palliative care for cancer or chronic lung disease. The total amount represents the agonizing state level of the collected material: low scoring means a better quality of the brain, and vice versa.

Considering these premortem conditions, we conclude that the ideal neuropathological study should avoid the use of brains of individuals with prolonged agonal state and 
TABLE - Sherwood index of agonal state ${ }^{(19)}$ used in neuropathological studies

\begin{tabular}{cc}
\hline Factors & Scoring \\
\hline Duration of agonal state & +1 for each nine months of duration \\
Seizures & 0 for absence; 1 for presence \\
Fever & 0 for absence; 1 for presence \\
Coma & 0 for absence; 1 for presence \\
Hypoglycemia & 0 for absence; 1 for evidence of; 2 for severity \\
Ingestion of neurotoxic substances & 0 for absence; 1 for presence \\
Dehydratation & 0 for absence; 1 for evidence of; 2 for severity \\
Mode of death & 0 to 4 \\
Multiple organ failure or traumatic brain injury & 0 for absence; 1 for presence \\
Hypoxic and/or ischemic brain macroscopic changes & 0 for absence; 1 for evidence of; 2 for severity \\
\hline
\end{tabular}

medical history of neurological and psychiatric diseases that can impair the analysis of the study. Before sample acquisition, it should be assessed whether cases will be restricted to an age group, or an specific gender, aiming to reduce the bias related to age and sex. Therefore, a wide-ranging and detailed recording of data on premortem conditions above mentioned is essential for further quality control of the material preservation process, and should be performed in all studies of postmortem nervous tissue.

\section{BRAIN POSTMORTEM CONDITIONS}

For educational purposes, we can classify three steps between the agonizing state and the brain removal: (1) the interval between the beginning of agonal stage until death; (2) the interval between the death and the body cooling; and (3) the interval between the body cooling and start of necropsy ${ }^{(13)}$. The postmortem interval (time between the death and start of necropsy) as well the temperature at which the body is maintained until brain removal, are relevant postmortem conditions that must be controlled during selection of individuals. It is known that temperatures above cooling $\left(>10^{\circ} \mathrm{C}\right)$ cause nucleic acids and proteins breakdown, and most proteins undergo structural and enzymatic activity changes at room temperature ${ }^{(6,7,12,13)}$. Shorter intervals between death and body cooling, and between cooling and necropsy, contribute to a lesser degradation of nervous tissue and greater quality of biological material.

As in premortem conditions, data about the periods in which brains were exposed to environmental variables until necropsy are essential for selecting the most suitable individuals to neuropathological studies. A detailed record of the postmortem conditions of each subject must be carried out in order to get a better view of a suitable postmortem nervous tissue for histological and molecular biology studies.

\section{POSTMORTEM BRAIN TISSUE CONSERVATION METHODS}

Before nervous tissue storage for long periods of time, most histochemistry and immunohistochemistry studies uses two steps in brain conservation: fixation and cryoprotection/freezing. The literature shows a wide variety of protocols used for both fixation and cryoprotection/freezing method, and the detailed knowledge of these methodologies contributes to a better final quality of the studied material.

\section{Brain fixation}

Fixation is the immersion of an organ or part of it in a substance with tissue conservation properties; aqueous formaldehyde is often used (commercially known as formol or formalin), or paraformaldehyde (PFA). PFA is a polymerized form that is transformed into more purified formaldehyde when diluted in water. PFA reduces the risk of fixative contamination by the formic acid, a product of formaldehyde oxidation that cause unwanted pigment artifacts in hemoglobin-rich tissues ${ }^{(8)}$.

Formaldehyde is transformed into methylene glycol in aqueous solution, acquiring high power of penetration in tissue (aproximately $1 \mathrm{~mm}$ per hour) and, within the material, the chemical equilibrium favors the conversion of methylene glycol into formaldehyde, which will fix the tissue ${ }^{(4)}$. It is believed that formaldehyde reacts with thiol group and amine of proteins and other macromolecules forming crosslinks which help to maintain the secondary, tertiary, and quaternary structure of proteins ${ }^{(4,8,15)}$. 
Several factors influence aldehydes fixation, such as tissue $\mathrm{pH}$, fixative concentration, and temperature ${ }^{(4)}$. Regarding the temperature, the fixation speed increases directly proportional to temperature, and it is estimated that fixation occurs within 24 hours at room temperature $\left(25^{\circ} \mathrm{C}\right)$, and in 17 hours at $37^{\circ} \mathrm{C}^{(8)}$. Furthermore, the reaction at higher temperatures reduces the risk of tissue retraction, causing no morphological changes of great relevance in the material at this stage ${ }^{(8)}$. Although producing tissue retraction in the smaller fragments, the $10 \%$ formaldehyde fixation usually causes a small, though variable, increase in brain weight ${ }^{(3)}$. It is used $10 \%$ formaldehyde concentration for fixation, or 4\% PFA (both 1.3 molar solutions), since they cause minor variations in staining results ${ }^{(8)}$.

An important aspect of aldehyde fixations is the need for antigen retrieval procedure in the samples to be submitted to immunohistochemistry. Crosslinks formation conserves protein structure by fixation and generates steric barriers that inhibit contact between antigens epitopes and antibodies used in immunohistochemistry, preventing the antigen-antibody reaction and generating false negative immunostaining. Antigen retrieval is a procedure that restores the expression of these blocked epitopes and optimizes the immunohistochemical staining. There are many protocols in the literature, used for nervous tissue, that are effective in antigen retrieval ${ }^{(4)}$.

Based on higher purity of the fixing solution and less chance of artifacts, most studies and our experience suggest the use of $4 \%$ PFA as a fixative for postmortem nervous tissue, at room temperature. Fixation time will depend on the sample volume and the specificities of structures of interest: some proteins, such as neuronal nitric oxide synthase (nNOS), are undetectable after fixation periods exceeding 48 hours ${ }^{(9)}$. We suggest a fixation time that do not exceeds 48 hours for samples previously sectioned and dissected, with thickness up to $1 \mathrm{~cm}$.

It is essential all brains used in the study may be fixed with the same protocol to prevent staining and morphometric variations among samples.

\section{Cryoprotection and freezing}

After fixation, the sample must be prepared for long-term storage of structures of interest, using freezing. Freezing also prevents diffusion of enzymes to locations different from their site in vivo ${ }^{(18)}$, and is the recommended conservation method for enzyme-histochemical studies. To prevent freezing artifacts, which can conflict with the morphological analysis of histological sections $^{(18)}$, it is important to control the sample freezing time: for longer periods, there will be extracellular ice crystals formation, which change tissue structure (Figure 1); for faster freezing, there will be intracelullar crystals formation and potential mechanical breakage of cell membrane ${ }^{(20)}$. A method used to get an optimal freezing rate is the pre-freezing in cryoprotectant substances, such as sucrose, glycerol, and dimethyl-sulfoxide, which prevent osmotic stress and cells rupture ${ }^{(13,18)}$.

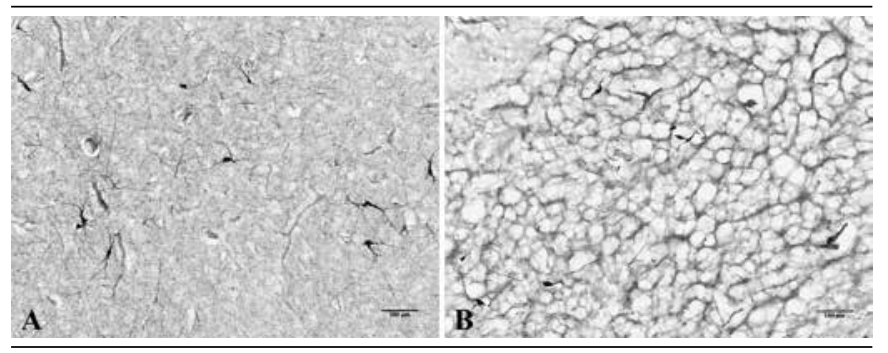

FIGURE 1 - Microscopic appearance of freezing artifact

A) putamen showing unchanged neuropil, with preserved cells and fibers morphology, in brain tissue frozen at optimal speed; B) freezing artifact in putamen, with cavities formation of extracellular ice crystals and tissue displacement caused by low speed freezing. 100x magnification, NADPHd staining.

NADPHd: nicotinamide adenine dinucleotide phosphate diaphorase.

Sucrose is a iso-osmotic, non-toxic, and low cost cryoprotectant, that provides slow and homogeneous reduction of temperature in the rapid freezing, thus reducing the risk of freezing $\operatorname{artifacts}^{(13)}$. The fixed brain tissue is immersed in sucrose solution, for variable periods of time and solution concentrations, in cooling temperature $\left(4^{\circ} \mathrm{C}\right)$. Sample sinking to the bottom of the container is used as criterion to confirm that the fragment is suitable for freezing. The gradual increase of solution concentration is suggested to reduce the impact of sharp change in osmolarity of the medium ${ }^{(20)}$. Cryoprotection with sucrose for an extended period of time has the disadvantage of potential sample contamination by microorganisms.

After cryoprotection phase, the nervous tissue is suitable for freezing at $-70^{\circ} \mathrm{C}$ to $-80^{\circ} \mathrm{C}$, leading to an extreme reduction of protein degradation and the formation of a rigid ice matrix in the fragment; thereafter, the sample can be stored until its use ${ }^{(5)}$. The thawing procedure must occur with no disruption of cellular compartments, thereby preventing macromolecules displacement ${ }^{(17)}$.

There are many freezing methods based on the use of simple freeze agents (liquid nitrogen and dry ice), or freezing by substitution method. Freezing by substitution is performed by an organic solvent that optimizes heat transfer from the sample to the dry ice, and dissolve the ice crystals formed in the tissue by freezing, forming a matrix which prevents the displacement of tissue intracytoplasmic structures ${ }^{(5)}$. 
Comparing with simple freeze agents, the freezing by substitution method has the advantage of reducing cell membranes disruption and accelerating the decrease of tissue temperature ${ }^{(2,18)}$. Isopentane is the most commonly used substance in freezing by substitution. In a comparison between the two freezing methods (with isopentane and powder dry ice), isopentane reduced the sample temperature twice fast as the dry ice and produced fewer freezing artifacts ${ }^{(18)}$. Isopentane is a cheap substance, therefore it is a good option for freezing postmortem brain tissue, but is highly flammable and must be handled with safety equipment.

These conservation methods prepare the material for storage at very low temperatures $\left(-70^{\circ} \mathrm{C}\right.$ to $\left.-80^{\circ} \mathrm{C}\right)$, which will allow the viability of greater concentration and diversity of proteins and other biomolecules, while maintaining the histological structures integrity for many years. Sample storage only in aldehyde for a longterm and storage by rapid freezing in liquid nitrogen at $-180^{\circ} \mathrm{C}$ have the disadvantages of impairing the detection of certain molecules, such as nNOS, and to destroy cell structures, respectively.

Considering these evidences, we suggest the use of sucrose solution (30\% or increased concentrations) until sinking of material as cryoprotective method, followed by rapid freezing by substitution with isopentane for postmortem nervous tissue samples with histological study purposes.

After storage, the samples will be ready for neuropathological analysis, which should be carefully thawed, sectioned in cryostat device, and undergo to histochemistry and immunohistochemistry specific procedures.

\section{A NEW PROPOSAL FOR ANALYSIS OF POSTMORTEM BRAIN TISSUE QUALITY}

In a recent study, our group evaluated the presence of a constitutional protein in neurons, responsible for the synthesis of nitric oxide (NO): nNOS. This study was designed to evaluate enzymatic activity and to detect the presence of this protein in neurons found in specific regions of the brain of individuals without neurological or psychiatric disorders, using histochemistry for nicotinamide adenine dinucleotide phosphate-diaphorase enzyme (NADPHd) and immunohistochemistry for nNOS, respectively ${ }^{(1)}$. nNOS can be degraded in long postmortem intervals ${ }^{(12)}$ and long periods of aldehyde fixation ${ }^{(9)}$, requiring a special strategy for fast removal of brain samples and fixation/freezing for a short period of time, to prevent protein degradation.
Due to the fragility of nNOS protein to external factors and potential failure on neuronal staining, mainly in histochemistry, we performed systematic recording of data, including: demographic data (sex, age, and collected hemisphere), clinical data (previous diseases, use of long-term medications, alcohol dependence, and clinical conditions in agonal state), and variables associated with postmortem period (intervals between "death and fixation", "fixation and cryoprotection", "cryoprotection and freezing", and storage) of all studied individuals.

After required histochemical and immunohistochemical staining, histological parameters were defined to evaluate the quality level of the resulting sections. Three numerical variables were used as quality parameters of histological staining: (1) density of neurons with nitrergic activity $\left(\right.$ cells $\left./ \mathrm{mm}^{2}\right)$ stained by histochemistry for NADPHd; (2) intensity of blue in sections stained by NADPHd, using a score from 0 to 4 , based on visual subjective criteria (Figure 2); and (3) density of total neurons $\left(\right.$ cells $/ \mathrm{mm}^{2}$ ) stained by immunohistochemistry for a different structural protein, the neuron-specific nuclear protein (NeuN), present in almost all neurons of nervous system.

Aiming to know the influence of external factors (premortem, postmortem, and tissue conservation conditions) over the enzymatic activity and detection of nNOS protein, multivariate linear regression models were established to analyze correlations

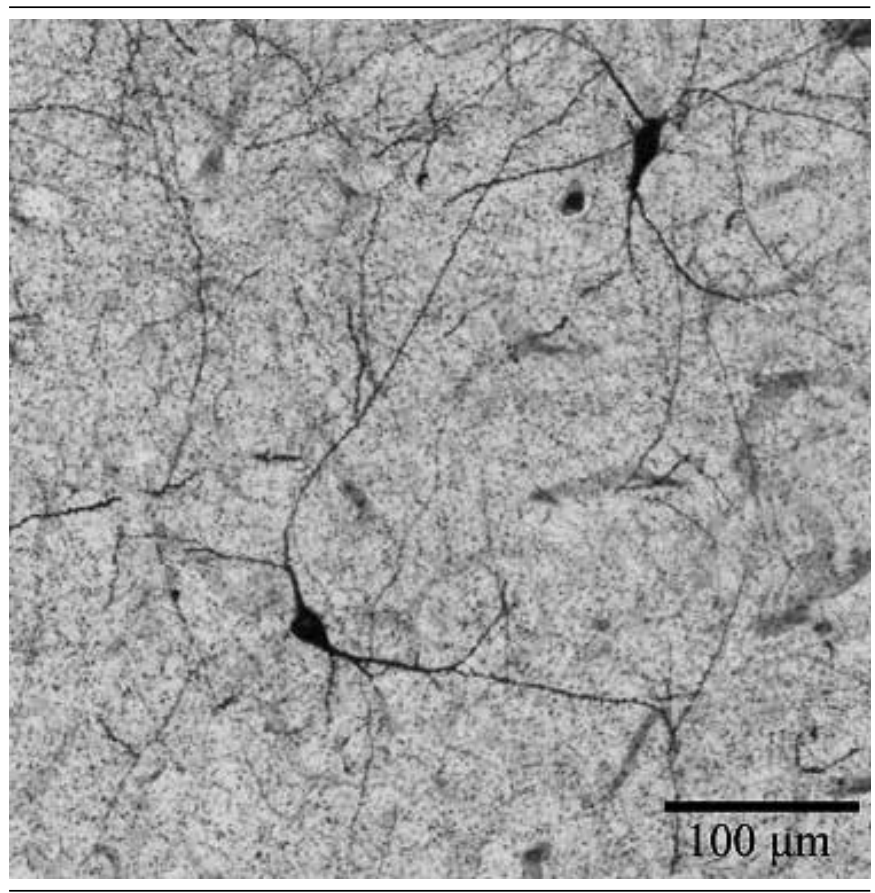

FIGURE 2 - Photomicrographs of striatal neurons which synthesize NO, stained by histochemistry. $100 \times$ magnification, NADPHd staining

NO: nitric oxide; NADPHd: nicotinamide adenine dinucleotide phosphate diaphorase. 
between the numerical variables associated with the most relevant external factors (individual age at death, agonal state measured by Sherwood index of agonal state ${ }^{(19)}$, interval of time between "death and fixation" and "fixation and cryoprotection") and the three numeric parameters of histological staining. It was observed no effect of external factors evaluated over the staining quality parameters (backwise method, model correlating all predictors and the density of nitrergic neurons: $p=0.309$; model correlating all predictors and the intensity of blue: $p=0.964$; model correlating all predictors and the density of total neurons: $p=0.62$ ), showing there was no degradation of histological staining signal caused by the tested variables.

These analysis based on basic statistical methods added reliability to the results, showing that pre and postmortem factors did not influence the analysis of nNOS protein activity and detection. Therefore, we recommend the use of these statistical strategies in postmortem human brain tissue studies to reinforce the validity of the results.

Furthermore, these data show that the use of a processing protocol based on a short postmortem period of time, 4\% PFA fixation, sucrose cryoprotection, and freezing with isopentane was effective in preventing the degradation of a protein of poor stability as nNOS.

\section{CONCLUSION}

The postmortem human brain tissue preservation is influenced by external factors, such as either premortem and postmortem conditions and the methods of preservation (fixation and freezing). The strict control of these variables is critical for good results in histochemistry and immunohistochemical studies. Neuropathological studies designed to detect proteins and other specific macromolecules should follow processing protocols with short postmortem time interval, aldehyde fixation, cryoprotection/ freezing, and storage at very low temperatures. Considering the potential deterioration of the brain caused by these external factors prior and after the death, the use of simple statistical tests which measure the degree of influence of these variables over the quality of postmortem brain tissue can be useful.

\section{RESUMO}

Os estudos neuropatológicos são fundamentais para novas descobertas sobre a fisiopatologia e o tratamento de doenças neurodegenerativas, como a doença de Alzheimer e a doença de Parkinson. 0 modo como o encéfalo pós-morte é processado influencia diretamente na adequada integridade e na detecção de biomoléculas por diferentes técnicas histológicas e de biologia molecular. Nesta revisão, abordaremos tópicos sobre a influência de determinados fatores externos sobre a preservação do encéfalo para estudos histológicos (bistoquímica e imuno-histoquímica), como as condições anteriores e posteriores ao óbito, e o método escolhido de conservação do tecido nervoso. Por meio de um exemplo específico, propomos um rigoroso registro das diversas condições envolvidas no processo de preservação do tecido nervoso e sua correlação com variáveis que avaliam a qualidade da amostra histológica, como marcadores da preservação do material biológico para estudos posteriores..

Unitermos: tecido encefálico pós-morte bumano; banco de encéfalo; neuropatologia; estado agônico; fixação; congelamento.

\section{REFERENCES}

1. BEESLEY, J. E. Histochemical methods for detecting nitric oxide synthase. Histochem J, v. 27, n. 10, p. 757-69, 1995.

2. BRATTHAUER, G. L. Preparation of frozen sections for analysis. Methods Mol Biol, v. 588, p. 67-73, 2010.

3. DUCHEN, L.W. General pathology of neurons and neuroglia. In: HUME ADAMS, J.; DUCHEN, L.W. Greenfield's Neuropathology. 5. ed. New York: Oxford University Press, 1992. p. 1-68.

4. EVERS, P.; UYLINGS, H. B.; SUURMEIJER, A. J. Antigen retrieval in formaldehyde-fixed human brain tissue. Methods, v. 15, n. 2, p. 133-40, 1998.
5. FEDER, N.; SIDMAN, R. L. Methods and principles of fixation by freezesubstitution.J Biophys Biochem Cytol, v. 4, n. 5, p. 593-600, 1958.

6. FERRER, I. et al. Brain protein preservation largely depends on the postmortem storage temperature: implications for study of proteins in human neurologic diseases and management of brain banks: a BrainNet Europe Study. J Neuropathol Exp Neurol, v. 66, n. 1, p. 35-46, 2007.

7. FERRER, I. et al. Brain banks: benefits, limitations and cautions concerning the use of post-mortem brain tissue for molecular studies. Cell Tissue Bank, v. 9, n. 3, p. 181-94, 2008.

8. FOX, C. H. et al. Formaldehyde fixation.J Histochem Cytochem, v. 33, n. 8, p. $845-53,1985$. 
9. GONZALEZ-HERNANDEZ, T.; DE LA CRUZ, M. A. P.; MANTOLANSARMIENTO, B. Histochemical and immunohistochemical detection of neurons that produce nitric oxide: effect of different fixative parameters and immunoreactivity against non-neuronal NOS antisera.J Histochem Cytochem, v. 44, n. 12, p. 1399-413, 1996.

10. HARDY, J. A. et al. The patients dying after long terminal phase have acidotic brains; Implications for biochemical measurements on autopsy tissue.J Neural Transm, v. 61, n. 253-64, 1985.

11. HARRISON, P. J.; PEARSON, R. C. In situ hybridization histochemistry and the study of gene expression in the human brain. Prog Neurobiol, v. 34, n. 4, p. 271-312, 1990.

12. HILBIG, H. et al. Influence of post-mortem delay and storage temperature on the immunohistochemical detection of antigens in the CNS of mice. Exp Toxicol Pathol, v. 56, n. 3, p. 159-71, 2004.

13. HYND, M. R. et al. Biochemical and molecular studies using human autopsy brain tissue. J Neurochem, v. 85, n. 3, p. 543-62, 2003 .

14. JOHNSTON, N. L. et al. Multivariate analysis of RNA levels from postmortem human brains as measured by three different methods of RT-PCR. Stanley Neuropathology Consortium. J Neurosci Methods, v. 77, n. 1, p. 83-92, 1997.
15. MASON, J. T.; O'LEARY, T. J. Effects of formaldehyde fixation on protein secondary structure: a calorimetric and infrared spectroscopic investigation.J Histochem Cytochem, v. 39, n. 2, p. 225-9, 1991.

16. MONORANU, C. M. et al. pH measurement as quality control on human post mortem brain tissue: a study of the BrainNet Europe consortium. Neuropathol Appl Neurobiol, v. 35, n. 3, p. 329-37, 2009.

17. PRENTØ, P. The effects of freezing, storage, and thawing on cell compartment integrity and ultrastructure. Histochem Cell Biol, v. 108, n. 6, p. 543-7, 1997.

18. ROSENE, D. L.; ROY, N. J.; DAVIS, B. J. A cryoprotection method that facilitates cutting frozen sections of whole monkey brains for histological and histochemical processing without freezing artifact. J Histochem Cytochem, v. 34, n. 10, p. 1301-15, 1986.

19. SHERWOOD, K. et al. A new index of agonal state for neurological disease. Neuropathol Appl Neurobiol, v. 37, n. 6, p. 672-5, 2011.

20. SHIRAKASHI, R.; TANASAWA, I. Method of designing pre-freezing protocol in cryopreservation of biological materials. Ann N Y Acad Sci, v. 858, p. $175-82,1998$.

21. TOMITA, H. et al. Effect of agonal and postmortem factors on gene expression profile: quality control in microarray analyses of postmortem human brain. Biol Psychiatry, v. 55, n. 4, p. 346-52, 2004. 